\title{
Central Giant Cell Granuloma with Cosmetic Deformity and its Treatment without A Scar
}

\section{Kozmetik Deformiteye Neden Olan Santral Dev Hücreli Granülom ve Skarsız Tedavisi}

\author{
(1) Banu Atalay Erdoğan1,2 \\ ${ }^{1}$ Bahçeșehir University Faculty of Medicine, Department of Otolaryngology, istanbul, Turkey \\ 2VM Medicalpark Pendik Hospital, Clinic of Otolaryngology, İstanbul, Turkey
}

\begin{abstract}
Central giant cell granuloma is a non-neoplastic proliferative lesion of unknown aetiology, and may cause severe local destruction. It occurs mostly in the mandible, but can also be found in the maxilla. Surgical excision is the mainstay of treatment. We managed this case by curettage via intranasal incision without producing external scar in a young woman.
\end{abstract}

Keywords: Giant cell granuloma, maxilla, swelling

\section{ÖZ}

Santral dev hücreli granülom, etiyolojisi bilinmeyen neoplastik olmayan proliferatif lezyondur. Ciddi yerel tahribata yol açabilir. En sık mandibulada görülür, ancak maksillada da oluşabilir. Cerrahi eksizyon, tedavinin temelidir. Bu olguda, genç bir kadında yara izi oluşturmadan intranazal insizyon yoluyla kitleyi kürete etmeyi başardık.

Anahtar Kelimeler: Dev hücreli granülom, maksilla, șişlik

\section{Introduction}

Giant cell granuloma (GCG) was first described by Jaffe in 1953 (1). The etiology of GCG is uncertain but may be related to the reactive response of intraosseous haemorrhage following trauma. GCGs are most often located in the maxilla and mandible (2). The second most common locations are hands and feet bones. GCGs are seen at any age but they tend to appear between ages of 25-40 (3). Despite their benign nature, GCGs may be locally aggressive. We report a case of GCG of the anterior maxilla with cosmetic deformity.

\section{Case Report}

Written informed consent was obtained from the patient. A 17-year-old female patient presented with a swelling on the left side of the face for two months. The swelling had progressed slowly from a small lesion to the present size. She was a nonsmoker with an unremarkable medical and family history. Examination revealed a diffuse swelling on the left side of the face causing the obliteration of the nasolabial fold resulting in facial asymmetry. The overlying skin was normal. On oral examination, there was a swelling in the labial aspect extending from the midline in relation to the upper left central incisor to the second premolar posteriorly obliterating the labial sulcus. It had a smooth surface with no evidence of fluctuation on palpation. The rest of the ear, nose and throat
(ENT) examination was normal. Serum calcium, phosphorus and alkaline phosphatase levels were normal.

A computed tomography (CT) scan (Figure 1) showed a $32 \times 22 \mathrm{~mm}$ expansile lesion involving the left maxillary bone. It caused erosion in the anteromedial wall of left maxillary sinus and the mass reached the subcutaneous tissue. Odontogenic fibroma, odontogenic cyst, odontogenic myxoma, adenomatoid odontogenic tumour and desmoplastic ameloblastoma were considered as differential diagnosis.

The patient underwent surgical resection with an incision from the superior to the left inferior nasal concha. The thickened cyst wall was lifted from the bony walls and the mass removed completely by curettage. The bony wall remnants were curetted. Histopathologic examination revealed a fibroblastic proliferation with rich osteoclast-like polynuclear giant cells and areas of haemorrhage (Figure 2). There was no recurrence after a follow-up period of 5 years.

\section{Discussion}

The World Health Organisation defines GCG as a benign intraosseous lesion consisting of fibrous tissue containing foci of haemorrhage and haemosiderin deposits, aggregations of giant cells and reactive bone formation (4). Its aetiology is not clear but many researchers agree
Address for Correspondence/Yazıșma Adresi: Banu Atalay Erdoğan MD, Bahçeșehir University Faculty of Medicine, Department of Otolaryngology; VM Medicalpark Pendik Hospital, Clinic of Otolaryngolog, İstanbul, Turkey Phone: +90 5062480466 E-mail: banuatalay81@gmail.com 0RCID ID: orcid.org/0000-0002-2956-23791

Cite this article as/Atıf: Atalay Erdoğan B. Central Giant Cell Granuloma with Cosmetic Deformity and its Treatment without a Scar. İstanbul Med J 2020; 21(4): 330-2.
Received/Gelis Tarihi: 22.09.2019 Accepted/Kabul Tarihi: 11.05.2020

(C) Copyright 2020 by the University of Health Sciences Turkey, Istanbul Training and Research Hospital/istanbul Medical Journal published by Galenos Publishing House.

(C) Telif Hakkı 2020 Sağıı Bilimleri Üniversitesi Istanbul Ĕgitim ve Araştırma Hastanesi/Istanbul Tıp Dergisi, Galenos Yayınevi tarafından basılmıștır. 
that they occur due to the repair process after damage (5). Giant cell reparative granuloma involves the mandible more often than the maxilla (6).

GCGs have two types; central (CGCG) or peripheral (PGCG). Central lesions develop inside the bone and peripheral lesions originate from gingiva or edentulous alveolar mucosa in the oral cavity. CGCG is rarely seen compared to PGCG (7). There is no histological difference between central and peripheral giant cell reparative granulomas. PGCG can be seen at any age, but usually, affect individuals between the ages of 4060 , and occur more frequently in females (8). CGCG affects females more often, and are encountered in individuals below 30 years of age (9). The clinical behaviour of CGCG is variable. It ranges from slow-growing, asymptomatic swellings to aggressive lesions which manifest with pain. Despite their benign nature, they may be locally aggressive. The most common presenting symptom of CGCG is a painless swelling with noticeable facial asymmetry (3).

Histopathological findings of GCG are multinucleated giant cells mixed with mononuclear stromal cells, both spindle- and round shaped cells, and found mostly in areas of haemorrhages. Radiological findings of


Figure 1. Computed tomography in coronal and axial sections of paranasal sinuses showing a 32×22 mm expansile lesion involving the left maxillary bone. This lesion causes an erosion in the anteromedial wall of left maxillary sinus and the mass reaches the subcutaneous tissue

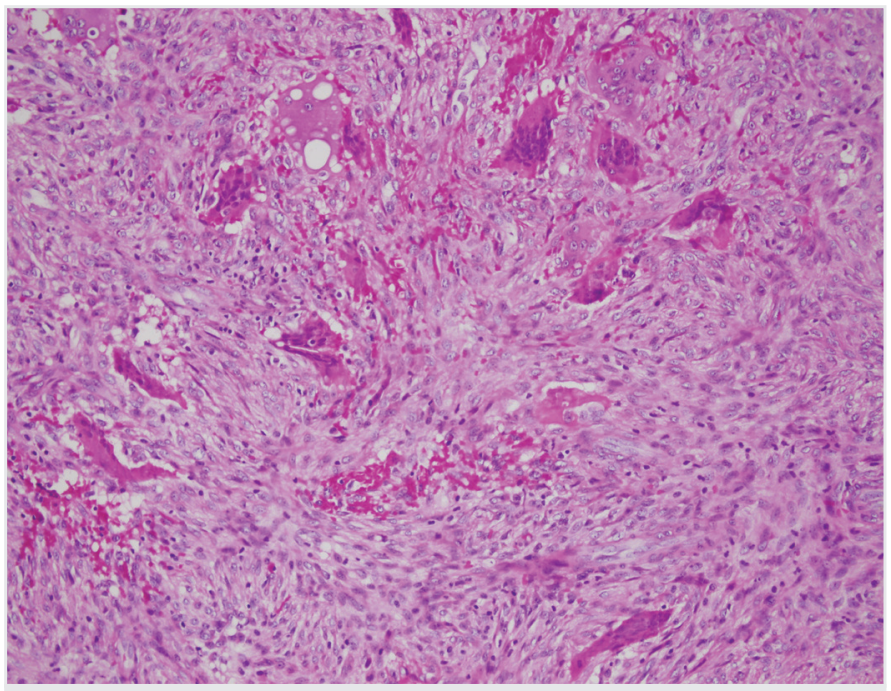

Figure 2. Histological findings of central giant cell granuloma: the tumour consists of spindled fibroblasts admixed with numerous multinucleated giant cells that tend to be arranged in small clusters
GCG are nonspecific. It usually appears as a unilocular or multilocular radiolucency that shows variable expansion and destruction of the cortical plate (3). Magnetic resonance imaging is the best modality for evaluating the extension of the lesion.

Surgery is the gold standard treatment for GCG. It ranges from curettage and simple excision to en bloc resection and reconstruction. Farrier et al. (10) suggested that complete surgical excision with curettage proved to be effective in the complete elimination of the lesion. However, it could recur after incomplete removal, ranging from $10-15 \%$ (11). Moreover, aggressive GCG grows fast, and tends to recur. Characteristic features of aggressive GCG include maxillary location, young age, pain, paraesthesia, and tooth root and cortical erosion (12).

In this case, the mass could not be palpated through the mouth. Since the patient was a young woman, we decided to use the intranasal approach. The mass was easily reached through an incision over the inferior nasal concha, and an excision was made so the patient had no facial scar.

Medical management of GCG, as an adjunct to surgery, involves treatment with steroids or calcitonin, which inhibit osteoclastic activity (13). In addition, interferon-alpha bisphosphonates and denosumab appear to be useful in its management. Some authors have advocated the use of medical agents only for aggressive and large lesions, due to systemic side effects (14). Radiotherapy may be suggested in cases of recurrence or unresectable tumours. However, it should be noted that some GCGs are radioresistant, with sarcomatous transformation possibly taking place over time (15).

\section{Conclusion}

GCG are benign osteolytic lesions, but because of their clinical appearance, patients usually worry about the characteristic of the lesions. Surgery is the gold standard treatment modality. In this case report, we present a patient with central giant cell reparative granuloma which causes facial deformity in a young woman. We treated her with an intranasal approach without incision scar.

\section{Ethics}

Informed Consent: Written informed consent was obtained from the patient.

Peer-review: Internally peer-reviewed.

Conflict of Interest: No conflict of interest was declared by the authors.

Financial Disclosure: The authors declared that this study received no financial support.

\section{References}

1. Jaffe HL. Giant-cell reparative granuloma, traumatic bone cyst, and fibrous (fibro-osseous) dysplasia of the jawbones. Oral Surg Oral Med Oral Pathol 1953; 6; 159-75.

2. Boedeker CC, Kayser G, Ridder GJ, Maier W, Schipper J. Giant-cell reparative granuloma of the temporal bone: a case report and review of the literature. Ear Nose Throat J. 2003; 82: 926-37.

3. Ebrahimi H, Yazdani J, Pourshahidi S, Esmaeli F, Zenouz AT, Mehdipour M Central giant cell granuloma of the posterior maxilla: a case report. J Dent Res Dent Clin Dent Prospects 2008; 2: 71-5. 
4. Uzbek UH, Mushtaq I. Giant cell granuloma of the maxilla. J Ayub Med Coll Abbottabad 2007; 19: 93.

5. Motamedi MH, Eshghyar N, Jafari SM, Lassemi E, Navi F, Abbas FM, et al. Peripheral and central giant cell granulomas of the jaws: a demographic study. Oral Surg Oral Med Oral Pathol Oral Radiol Endod 2007; 103: 39-43.

6. Ishinaga H, Otsu K, Mouri G, Takeuchi K. Aggressive giant cell reparative granuloma of the nasal cavity. Case Rep Otolaryngol. 2013; 2013: 69019.

7. Cayci E, Kan B, Guzeldemir-Akcakanat E, Muezzinoglu B. Peripheral giant cell reparative granuloma of maxilla in a patient with aggressive periodontitis. Oral Health Dent Manag 2014;13: 638-41.

8. Katsikeris N, Kakarantza-Angelopoulou E. Peripheral giant cell granuloma. clinico-pathologic study of 224 new cases and 956 reported cases. Int J Oral Maxillofac Surg 1988; 17: 94-9.

9. Neville BW, Damm DD, Allen CM, Bouquot JE. Oral and Maxillofacial Pathology. 4th ed. Philadelphia: Saunders; 2002.pp.705-40.

10. Farrier SL, Farrier JN, Smart MK, Nash ES. A 10-year review of the occurrence and treatment of central giant cell granulomas, in a District General Hospital. J Oral Pathol Med 2006; 35: 332-7.
11. Günel C, Erpek G, Meteoğlu I. Giant cell reparative granuloma in the hard palate. International Journal of Pediatric Otorhinolaryngology Extra 2007; 2 : 76-9.

12. Roberts J, Shores C, Rose AS. Surgical treatment is warranted in aggressive central giant cell granuloma: a report of 2 cases. Ear Nose Throat J 2009; 88: 8-13.

13. de Mendonça RP, Mitre GP, Real FH, da Silva Kataoka MS, de Melo Alves Júnior $S$, Vianna $P$, et al. Central giant cell granuloma treated with intralesional corticosteroid injections and bisphosphonates: a long-term follow-up case study. Head Neck Pathol. 2019 Jul 11. doi: 10.1007/s12105-019-01053-x. [Epub ahead of print].

14. Schreuder WH, van den Berg H, Westermann AM, Peacock ZS, de Lange J. Pharmacological and surgical therapy for the central giant cell granuloma: A long-term retrospective cohort study. J Craniomaxillofac Surg 2017; 45: 23243.

15. Akhtar MU, Nazir A, Imtiaz M. Unusual case of maxillary giant cell granuloma: management, functional and aesthetic rehabilitation. Annals of King Edward Medical University 2014; 20: 113-6. 